\title{
Discussion on College Education Management
}

\section{Chunfu Yang ${ }^{1, a}$, Dongliang Yang ${ }^{2, b}$, Weihong Min $^{3{ }^{*} \mathrm{c}}$}

${ }^{1}$ College of Animal Science and Technology, Jilin Agricultural University, Changchun 130118, China

${ }^{2}$ College of Information and Technology, Jilin Agricultural University, Changchun 130118, China

${ }^{3}$ College of Food Science and Engineering, Jilin Agricultural University, Changchun 130118, China

ayangchunfu197242@163.com, b610557217@qq.com, '65817713@qq.com

${ }^{*}$ Corresponding author: Weihong Min, Professor, female, born in August, 1971, interested in food science.

Keywords: New Era; New Situation; Existing Problems of College Education Management; Countermeasures and Suggestions

\begin{abstract}
Along with the deep reform of college, there are new requirements on college education management. The authors come up with a glittering array of countermeasures and suggestions to dig into the problems of college education, and scientifically improve the quality of college education, aiming to carry out some beneficial explorations and attempts to the college education management and its related new development modes. College education management is the core to improve the quality and comprehensive ability of college education, which is also an effective guarantee to improve the quality of overall work performance. In addition, with the deeper reform carried out by colleges, the task to improve college education management becomes complicated, highlighted and urgent. How to comprehensively improve the college education work is of pivotal
\end{abstract}

\section{Problems of College Education Management Needed To Be Solved Urgently}

Education Management Philosophy Is Old. The humanism idea of college education is become more and more prominent; however, the management idea of education managers is still. They still keep the ideas of planned economic period; ignore the main status of teachers and students as well as objective reality. In addition, obsolete notions such as power domination and empirical experience imprison some people's mind while the main status of teachers and students is being diluted. Based on this, their passion will face and the teaching management will be conceptual, modeling and unified. As a result, the teaching management philosophy will get divorced from reality, which will inevitably limit the development of teacher and students' passion and bring about difficult for management [1]

Education Management Mode Is Rigid. At present, colleges in China develop rapidly while the number of schools, departments and running scale of colleges is expanding and the faculty quality is getting better. It is a good situation, but competitive which will inevitably ask the education management of colleges to conform to the development trend and conduct creative work. However, the teaching management mode of some colleges are single and rigid, and they adopt the same management mode on different schools and departments, and such cramming means is not flexible and cannot meet the requirement of different people, which will definitely doom to futility.[2] However, it is known to all that united management mode is more convenient, while its biggest demerit is that it confines the personality development of students, limits the innovative ideas of teachers and students. As a result, their teaching activities will inevitably become dull without energy and will affect the teaching quality improvement and the development of both students and teachers.

The Education Quality Evaluation System Is Not Scientific. The core of education management is to carry out supervision management on the education quality and trigger the passion and initiative of both teachers and students so as to achieve the accomplishment of education goal. However, the current education quality evaluation has problems, and it puts too 
much focus on quality supervision and ignores the implementation reform; highlights theory and neglects practice; weighs too much on the commonality and overlooks the individuality of subjects.[3] So, the evaluation indictor is rigid, which does not have particular indictors for different subjects. All in all, the evaluation methods for education quality is generalized and is not targeted, which is difficult to implement.

The Comprehensive Quality of The Education Management Teams Needs To Be Improved. Along with the implementation of college reform, the quality of education management team has been improved a lot. However, it cannot be adapted to the education development trend which develops rapidly. Most of the education managers cannot well understand the management rules and do not possess certain education experience. What's more, they cannot well understand the management work and their management ability is poor, they just do whatever they want. [4]Furthermore, there are not enough faculties in terms of management, who are not trained and cultivated, they only ask students to finish task without teaching them how to think. As a result, the whole management ability lags behind.

\section{Countermeasures and Suggestions to Strengthen College Education Management}

In order to build a management team with high quality, who can be adapted to the knowledge economy, and information development to comprehensively improve the scientific work and effectiveness and at the same time cultivate innovative talents, the authors put forward the following countermeasures and suggestions based on the existing disadvantages of college education management:

Highlight Education Management Philosophy. College education management should keep pace with time and have innovative methods. So-called innovation is to adhere to the philosophy of human-orientation and highlight the main status of teachers and students, explore their potential and trigger their passion. To begin with, we have to pay attention to the education management work. According to the development trend and deepening reform, we should strengthen management team construction, enroll enough faculties and clear their responsibility from the perspectives of position and function to fully recognize their status and tigger their passion and initiative.[5] Secondly, we have to respect the main status of teachers and students. In education management, we have to try unremitting efforts to create a good environment to respect teachers and talents, pay attention to their development and study on the individual requirement of teachers so as to continually stimulate their initiative and creativeness to fully play their talents. In addition, we should also respect the main status of students. Education management has to constantly strengthen the management philosophy of students-orientation according to the development trend and individual needs of students in order to perfect the education system construction. Furthermore, by doing this, we are able to determine and respect the main status of teachers and students and cultivate their independent learning ability and innovative ability. [6]

Optimize The Education Management Mode. The college education management mode should be diversified, which should consider cultivating all-round talents as the ultimate goal and highlight the main status of teachers and students. In addition, education management mode should be modern and democratic with relative education schemes. On the one hand, we should optimize various sectors of education, including modifying the education outline, class implementation and practical education management to flexibly teach students according to their aptitude. [7] On the other hand, we have to optimize the education quality evaluation, establish scientific, objective education quality evaluation standards, which is also a guarantee for excellent education management. Moreover, the comprehensive comment on education standards should also be highlighted. Besides teachers and students, the teaching principles, policies and systems should receive objective comments.

Perfect The Supervision and Evaluation System of Education Quality, Which is the Key to Scientifically Manage Education. To being with, we should strengthen and perfect the education quality supervision system and further elaborate the evaluation sectors, quantify the evaluation standards and fully bring teachers' enthusiasm into play. For example we should make regulations 
in terms of responsibilities, rules of conduct, operation procedures as well as system of encouragements and penalties with relative supervision assessment schemes to well implement education management. [8]What's more, we should constantly perfect the competition system to let talents shine out and dismiss those who cannot do this job so as to strengthen teachers' competitive consciousness. Furthermore, establish generous incentive mechanism. We can relate the individual development, promotion, salary standard and benefits to education quality and give more chances to those excellent teachers. [9]

Comprehensively Improve The Quality Of Education Managers. College education mimers are the main bodies of college education management, who play the leading role and we have to pay enough attention to them. To being with, we should cultivate talents with management ability and build a strong and powerful management team. [10]And they have to possess the ability of research and prediction so as to carry out prospective and tactical management methods and thus improve the comprehensive quality of education management. Secondly, we should strengthen the ideological and political quality of education mangers to possess the consciousness of politics and overall situation as well as good morality to be adapted to and keep pace with the time. Thirdly, they should master advanced education and management philosophy and have a good knowledge of the department nature, work rules and work direction. Fourthly, they have to constantly learn and innovate. [11] They have to try tireless efforts to improve their knowledge of science and culture and management. In addition, they should also constantly improve their innovative ability based on new situations and constantly come up with new management ideas according to market requirement, school development and education reform so as to improve the quality of education management. [12]

All in all, college education management has a direct effect on whether the college reform will be carried out orderly and whether the quality of talents is good or not. College education management should innovate the management philosophy, implement diversified education management mode, perfect the education quality assessment system, and strengthen the management team construction. Based on this, we can improve the education management ability from a comprehensive way from theory to practice, from subjective ability to objective system etc.

\section{References}

[1] Q.Y.He: Discuss on the standardization problem of college education management [J]. China after School Education, 2012.4. (In Chinese)

[2] Q.Wu and D.Z Wu.:Brief analysis on college education management [J]. Education and Teaching Forum, 2012.9. (In Chinese)

[3] Q.Li: Discuss on the new direction and development mode of college education management [J].Reform \& Opening, 2011.6. (In Chinese)

[4] W.Lin: Innovative talents cultivation and college education management reform [J]. Journal of Fujian Public Safety College, 2002.4. (In Chinese)

[5] C.H.Lan and Y.Qin: Discuss on the credit system and college education management reform [J]. Journal of Anshan Normal University, 2002.4. (In Chinese)

[6] J.X.Hu, P.Guan and Y.X.Chen: Comparative study on college education management modes and credit system of higher vocational schools [J]. Heilongjiang Researches on Higher Education, 2004.1. (In Chinese)

[7] G.C.Ye: Brief discussion on the college innovative system construction. Development Study, 2004.2. (In Chinese)

[8] L.N.Wang and H.B.Zhou: Countermeasures and problems for current college education management $[\mathrm{J}]$.Education Exploration, 2011.3. (In Chinese) 
[9] H.B.Liang and Z.G.Cui: Effective research on the college education quality management (Education research), 2010.6. (In Chinese)

[10] H.Wu and Z.Q.Cheng: Problems and countermeasures for college education management [J]. Journal of Hunan Business College, 2013.12. (In Chinese)

[11]Y.Jia: Brief study on the function of humanistic management for college education management $[\mathrm{J}]$. Private science and technology, 2016.9. (In Chinese)

[12]X.Wang: Brief study on the problems and countermeasures for college education management [J]. Private science and technology, 2016.9. (In Chinese) 